\title{
The Effect of Air Pressure on Foamed Mortar Production
}

\author{
Ibrahim $^{1}$ Amiruddin ${ }^{1}$ Ika Sulianti $^{1}$ Agus Subrianto ${ }^{1, *}$ Istiqomah Fajriani ${ }^{1}$ \\ Nauval Fardha Habib ${ }^{1}$
}

${ }^{1}$ State Polytechnic of Sriwijaya

${ }^{*}$ Corresponding author. Email: agussubrianto@gmail.com

\begin{abstract}
Foam mortar is a concrete-like material consisting of a mixture of sand, cement, water and foam agent. This material can be used as road embankment material due to its light weight, high enough strength for subgrade, bulk and compressive strength can be designed as desired so as to reduce the impact of subsidence on the road above. This research is carried out to produce foamed mortar with variations in air pressure and seeing the effect of changes in air pressure. Test results show that per 5 psi the decrease in air pressure decreases the compressive strength value at 28 days by $22.840 \%$ and decrease the dry density of foam mortar at 28 days by $9.298 \%$. The maximum compressive strength value occurs at the age of 28 days, varying by air pressure 30 psi, 35 psi, 40 psi, 46 psi and 50 psi are $5381,241 \mathrm{kPa}, 4058,758 \mathrm{kPa}, 3332,111 \mathrm{kPa}, 2376,055 \mathrm{kPa}$ and 1896,366 kPa respectively. The highest compressive strength value occurs on 30 psi air pressure variations. Foamed mortar, foam agent, air pressure, compressive strength, density
\end{abstract}

Keywords: Foamed Mortar, Foam Agent, Air Pressure, Compressive Strength, Density

\section{INTRODUCTION}

Generally, road embankment material uses high grade soil or aggregates which has high selfweight. Road embankment are often built on soft soils which have low soil bearing strength On peak soil, these heavyweight materials and also the traffic load can settle the weak subgrade structure. Once the lower level settles, we can find the basin on the surface of road, followed by water puddle and finally the road damage. The embankment settlement can also give additional pressure on bridge abutment and can make it collapse.

These problems can be overcome by hoarding using special materials such as the use of light pile technology consisting foam agent to make foamed concrete [1]. Foamed concrete is also used on another application widely from panel insulation to soil work [2], [3]. Currently, many road projects in Indonesia have been built using lightweight embankments which were developed as a technological innovation because they are self-compacted to become a substitute material for high grade soil [4].

Foam agent is a liquid when mixed with water will produce foam. In previous work [5], the formula was investigated for sub base layer specification. The variable was foam agent to water ratio : 1:20, 1:25, 1:30, $1: 35,1: 40$ by weight. Target were $\min 800 \mathrm{kPa}$ on compressive strength and max $0,6 \mathrm{ton} / \mathrm{m}^{3}$ of density for sub base layer. Conclusion obtained the ratio 1:30 foam to water ratio is the best performance to meet the both requirements. In that research it was also indicated that the change of air pressure on machine during production made the instability of mortar properties such as density and compressive strength. This phenomenon forced us to determine certain pressure to produce the mixture for specimen needed. Thus led us to observe the wider range of air pressure working on machine. Therefore, in this research we focus on variation of air pressure effect on foamed mortar characteristic.

\section{METHOD}

The best formula with composition 1:30 of foam to water ratio then used to carry out another investigation using the same materials. In this research the mortar performance is raised as sub base layer specification. The target are minimum $2000 \mathrm{kPa}$ of compressive strength and maximum 0.8 ton $/ \mathrm{m}^{3}$ of density. This values based on concencus of Ministry of Public Work 
about road embankment material using lightweight foamed concrete material [6].

This experiment uses Portland Cement Type I, sand as fine aggregate, tap water and foam agent to generate foamed mortar. The same materials as previous research retested to obtain cement concistency and the properties of fine aggregate.

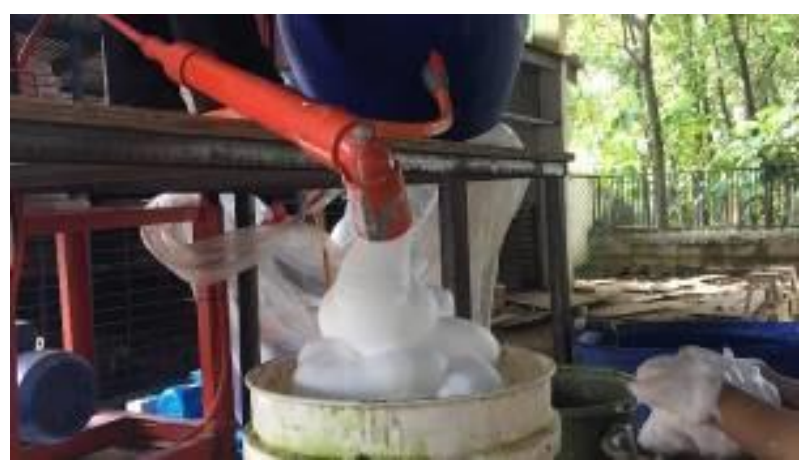

Figure 1. Generating foam solution

Before applying the variation of air pressure for all of speciment, the certain air pressure should be investigated to determine the best pressure giving the mortar density which meet requirement for sub base of road layer, namely $0.8 \mathrm{ton} / \mathrm{m}^{3}$. This step through trial and error for several mixture. The blended water and foam using Samacon foam generator then pondered after pressure given to obtain the density. After trial the $46 \mathrm{psi}$ of air pressure was found as predicted pressure would give around $0.8 \mathrm{ton} / \mathrm{m}^{3}$ of mortar density. So the air pressure range given for whole experiment are 30, 35, 40, 46 instead of 45 and 50psi. The value is started from 30 psi because we need to see how high of compressive strength and we close at 50 psi because the density should be satisfied on that value.

After the air pressure range is fixed, the next step is to mix the materials to ctreate the complete mixture. The number of speciment are 3 for each air pressure variable. The speciment were tested of its slump flow at fresh state and then also tested at 14, 21 and 28 days to obtain the density and compressive strength value. So the total number of tested were 45 speciments conducted by Humboldt unconfined compression test machine. All of hardened speciments are molded on cylinder shape of $100 \mathrm{~mm}$ diameter x $200 \mathrm{~mm}$ height. The method of curing is to cover speciments by wet sack starting from 3 days after opening of mold until the final day just before the compressive test performed.

\section{RESULTS AND DISCUSSION}

\subsection{Cement and Sand Properties}

The specific gravity of cement obtained was 3.048 $\mathrm{gr} / \mathrm{ml}$. The cement has 117 minutes of initial setting time and 195 minutes of final setting time respectively. Test results of sand are showed on Table 1. The value obtained are all pass the Indonesian standard requirements and showed that the values are almost same as previous tests.

Table 1. Properties of fine aggregate

\begin{tabular}{|l|c|}
\hline Properties & $\begin{array}{c}\text { Value } \\
\text { obtained }\end{array}$ \\
\hline Fine grain modulus & 3.4165 \\
\hline Dry specific gravty & 2.449 \\
\hline $\begin{array}{l}\text { Specivic gravity of saturated surface } \\
\text { dry }\end{array}$ & 2.51 \\
\hline Absorption (\%) & 2.48 \\
\hline Water content (\%) & 6.735 \\
\hline Mud content (\%) & 0.502 \\
\hline
\end{tabular}

The gradation of fine aggregate classified at zone 2 obtained from sieve analysis test.

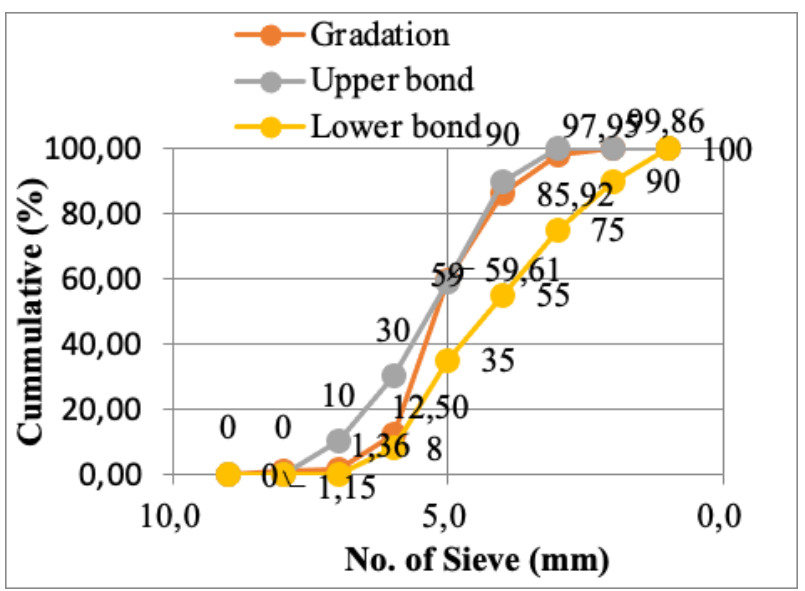

Figure 2. Sieve analysis result of sand

\subsection{Design Mix Formula}

Before determine the design mix formula, it is important to find out the satisfying pressure which will give the representative performance. The foam agent and water are blended to ctreate foam solution using foam generator with variation of air pressure. Each pressure variable consists 3 mixtures with the density measured are shown at Table 2 .

Table 2. Density of foam solution

\begin{tabular}{|c|c|}
\hline Air pressure (psi) & Average of Density $\left(\mathrm{t} / \mathrm{m}^{3}\right)$ \\
\hline 30 & 0.103 \\
\hline 35 & 0.101 \\
\hline 40 & 0.094 \\
\hline 47 & 0.077 \\
\hline 50 & 0.066 \\
\hline
\end{tabular}

From the table we can see that the higher air pressure given, the lower the density of foam solution. After measuring the solution density, the next step is to calculate the materials used for $1 \mathrm{~m}^{3}$ of foamed mortar. Based on calculation, the constituents of each material are changing from the previous mixture [5], because of 
the higher compressive strength needed. Calculation using the spreadsheet which is used by Centre of Road and Bridge specification. Table 3 shows the design mix formula for this research. The formula then converted in to the speciment cylinder

Table 3. Design mix formula

\begin{tabular}{|l|c|c|}
\hline \multicolumn{1}{|c|}{ Materials } & Value & Unit \\
\hline Cement & 445 & $\mathrm{~kg}$ \\
\hline Water & 209.2 & $\mathrm{~kg}$ \\
\hline Sand & 254.8 & $\mathrm{~kg}$ \\
\hline Foam & 544.9 & $\mathrm{Itr}$ \\
\hline Total weight & 949.8 & $\mathrm{~kg}$ \\
\hline
\end{tabular}

\subsection{Slump Flow}

The workability of mortar is important to investigate to make sure that there will be no problem during pouring of mortar on site. Test results of slump flow of foamed mortar are shown on table 4.

Table 4. Slump flow

\begin{tabular}{|c|c|}
\hline Air pressure $(\mathrm{psi})$ & Slump flow $(\mathrm{cm})$ \\
\hline 30 & 20 \\
\hline 35 & 19.7 \\
\hline 40 & 19.3 \\
\hline 47 & 18.3 \\
\hline 50 & 17.7 \\
\hline
\end{tabular}

The workability of mortar are decreased as higher air pressure applied. However, the slump of all speciment measured are satisfied for $18+-2 \mathrm{~cm}$ required. No special work needed to compact this mixture condition.

\subsection{Density of Mortar}

The dry density of mortar are measured just before they are tested for compressive strength and the results are shown at table 5 .

Table 5. Dry density of foamed mortar

\begin{tabular}{|c|c|c|c|}
\hline \multirow{2}{*}{$\begin{array}{c}\text { Air pressure } \\
(\text { psi) }\end{array}$} & \multicolumn{3}{|c|}{ Density (ton $/ \mathrm{m}^{3}$ ) } \\
\cline { 2 - 4 } & 14 days & 21 days & 28 days \\
\hline 30 & 1.19 & 1.17 & 1.16 \\
\hline 35 & 1.07 & 1.03 & 1.03 \\
\hline 40 & 0.97 & 0.96 & 0.96 \\
\hline 47 & 0.85 & 0.84 & 0.83 \\
\hline 50 & 0.82 & 0.80 & 0.78 \\
\hline
\end{tabular}

The density of dry mortar are decreased as the air pressure is raised. The higher pressure affects the foam swelling and then followed by the forming of void in mixture with more air trapped inside of mortar. These void contribute to make the weight of mortar lighter. We can also find that on the early age, mortar are heavier because of the water are still exist in the mixture. Because of the evaporation, the water immobilitated outside then the mixture going have more pore. We can also find at figure 3 that the density expected before is $0,826 \mathrm{ton} / \mathrm{m}^{3}$ occurs at 28 days with 46 psi of air pressure given. It is quite higher than the required as $0.8 \mathrm{ton} / \mathrm{m}^{3}$. This value is higher than previous research [5] because of the different of specification.

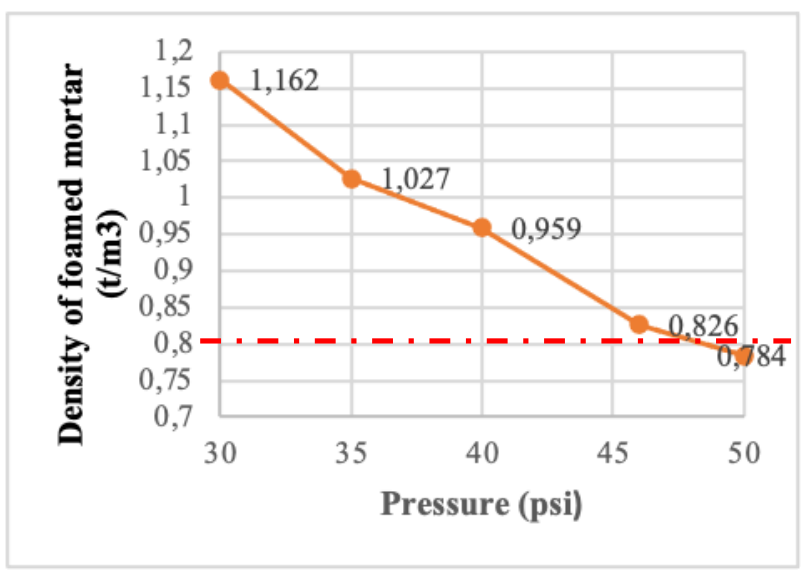

Figure 3. Dry density of foamed mortar at 28 days

\subsection{Compressive Strength of Mortar}

The compressive strength of normal mortar is much higher than the foamed mortar. The normal mortar could reach 13-17 $\mathrm{MPa}$ at 28 days with the same materials [5]. The significant of voids in mixture because addition of foam agent makes the compressive strength of foamed mortar decreases significantly. The table 6 below shows the compressive strength of foamed mortar at different age.

Table 6. Compressive strength of foamed mortar

\begin{tabular}{|c|c|c|c|}
\hline \multirow{2}{*}{$\begin{array}{c}\text { Air pressure } \\
\text { (psi) }\end{array}$} & \multicolumn{3}{|c|}{ Compressive strength $(\mathrm{kPa})$} \\
\cline { 2 - 4 } & 14 days & 21 days & 28 days \\
\hline 30 & 4374.6 & 4682.9 & 5381.2 \\
\hline 35 & 3718.0 & 3848.2 & 4058.8 \\
\hline 40 & 2950.3 & 3236.7 & 3332.1 \\
\hline 47 & 1582.8 & 2181.9 & 2376.1 \\
\hline 50 & 1273.8 & 1499.6 & 1896.4 \\
\hline
\end{tabular}

The density of mortar are decreased at 28 days, however the complete reaction of constituents make the mature mortar are ready to receive the load. Hence, the compressive strength are increased from 14 days to 21 days and also from 21 days to 28 days. The typical trend of foamed mortar compressive strength is represented by 28 days speciments shown on figure 4 . 


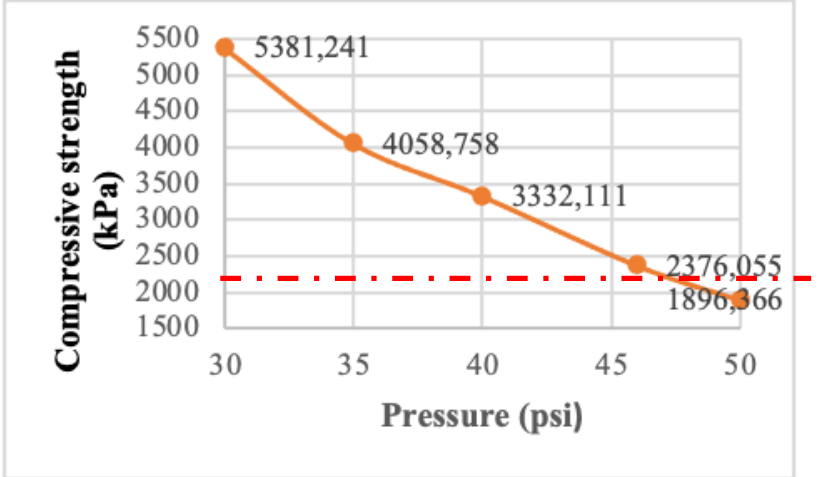

Figure 4. Compressive strength of foamed mortar at 28 days

The compressive strength is decreased as air pressure applied is raised. This is linear to behaviour of density of mortar. The compressive strength obtained for 46 psi air pressure is $2376.1 \mathrm{kPa}$, higher than 2000 $\mathrm{kPa}$ which is required as minimum value needed for sub base road layer. Something interesting here that the 46 psi of air pressure given and predicted earlier gives the most satisfied performance of foamed mortar. The density is quite higher than expected, but at least this pressure occurs the closest value for both variable investigated, density and compressive strength.

\section{CONCLUSION}

The laboratory experimental have tested the series of speciments to find out the effect of air pressure given during processing on the performance of foamed mortar. Base on result obtained we can conclude that:

1. The higher air pressure, the lower of the mortar compressive strength;

2. The higher air pressure, the lower of the mortar density;

3. The optimum of air pressure gives satisfied performance meets the requirement is $46 \mathrm{psi}$, or around that

This results answer the question on the field when the worker doing trial and error to find the level of air pressure needed to get the optimum performance of foamed mortar. However, the results may depend on the aggregate properties, condition of generator machine and the skill level of operator. Further research needed to apply this formula on field application, whether on mini scale or larger scale.

\section{ACKNOWLEDGMENTS}

The Authors thank to Ministry of Education and Culture of Republic of Indonesia to support this research through State Polytechnic of Sriwijaya annual funding.

\section{REFERENCES}

[1] Kadela M, Kozlowski M and Kukielka A. 2017 Application of Foamed Concrete in Road Pavement - Weak Soil System. Procedia Engineering193 436-446

[2] Mindess S. 2008 Development in the Formulation and Reinforcement of Concrete. Woodhead Publishing in Materials by CRC Press 231-255

[3] Loon L Y, Soon G K, boon K H, Bakar I. 2009 Foamed Aggregate Pervious Concrete-An Option for Road on Peat. Proceeding of MUCEET

[4] Iqbal M. 2012 Study of Soft Soil Treatment using Foamed Mortar Embankment. Puslitbang Jalan dan Jembatan. Bandung

[5] Subrianto A, Amiruddin, Ibrahim, Sulianti I, Nudia and Beladin S. 2012 Influence of foam to water ratio on compressive strength of foamed mortar as the road construction material. Journal of physics: Conference series, volume 1500, 3rd FIRST. Palembang. DOI: https://doi.org/10.1088/1742-6596/1500/1/012081

[6] Ministry of Public Work. 2011 Consensus R0 Guidelines on Road embankment design using lightweight foamed concrete material. 